\title{
Wildlife Population Change in Africa from the Eyes of the Public-The Case of Mara Enoonkishu Conservancy in Southern Kenya
}

\author{
Dorothy Syallow Masiga ${ }^{1 *}$, Francis Mwaura², Mikalitsa S. Mukhovi2 \\ ${ }^{1}$ University of Kabianga, Kericho, Kenya \\ ${ }^{2}$ Department of Geography \& Environmental Studies, University of Nairobi, Nairobi, Kenya \\ Email: *dsyallow@gmail.com
}

Received 2 June 2016; accepted 17 July 2016; published 20 July 2016

Copyright (C) 2016 by authors and Scientific Research Publishing Inc.

This work is licensed under the Creative Commons Attribution International License (CC BY). http://creativecommons.org/licenses/by/4.0/

(c) (i) Open Access

\section{Abstract}

The aims of the study were to: 1) determine the wildlife population trends in the Mara Enoonkishu Conservancy from the eyes and minds of the public, 2) assess the recent trends in wildlife populations based on actual scientific counts, and 3) compare the two patterns and establish whether they are similar or not. The solicitation of public views was based on household surveys using a standard questionnaire which was administered to 115 randomly selected respondents. The dominant wildlife species according to $39 \%$ of the respondents was the elephant followed by the zebra with $35 \% .40 \%$ of the respondents indicated that the rhino population had declined followed by wild dogs $(7 \%)$ and cheetah $(6 \%)$. The actual counts showed that the herbivores with increasing populations included the rhino $\left(r^{2}=0.9992\right)$, impala $\left(r^{2}=0.9824\right)$, Thomson's gazelle $\left(r^{2}=\right.$ $0.6965)$, Grant's gazelle $\left(r^{2}=0.7052\right)$, elephant $\left(r^{2}=0.5798\right)$, and topi $\left(r^{2}=0.4426\right)$ while the increasing predators included the lion $\left(r^{2}=1.000\right)$, cheetah $\left(r^{2}=0.9093\right)$ and hyena $\left(r^{2}=0.8462\right)$. The actual wildlife counts appeared to tally with the public views only for the elephant and zebra. The actual counts contradicted the public views in terms of the rhino, lion and gazelles whose numbers were on the increase but the people did not appear to notice. Based on this, it was concluded that the public view on the wildlife population trend was not similar to the actual wildlife population status on the ground based on scientific monitoring.

\section{Keywords}

Wildlife Population Change, Animal Counts, Public Perception

\footnotetext{
${ }^{*}$ Corresponding author.
}

How to cite this paper: Masiga, D.S., Mwaura, F. and Mukhovi, M.S. (2016) Wildlife Population Change in Africa from the Eyes of the Public-The Case of Mara Enoonkishu Conservancy in Southern Kenya. Natural Resources, 7, 434-444. 


\section{Introduction}

Africa is one of the world's best endowed in terms of wildlife heritage compared to other biogeographic regions in the world. Despite the important role of such heritage to the African economy through tourism, the continent's wildlife has continued to dwindle across almost taxonomic and national boundaries [1]-[3]. According to [4], Kenya has lost over $40 \%$ of its large fauna over the last few decades despite massive national effort even with the backing by various international conservation agencies. The population of elephants and rhinos in Kenya, for example, declined significantly by over $60 \%$ and $90 \%$, respectively during the last five decades [3]. Studies have shown that the country lost at least half of her elephants between the 1970s and 1980s alone [5] [6]. In 1973, the country had an estimated population of 130,000 elephants, down from more than 160,000 the previous year [5] [6]. Today, the population is probably less than 50,000. Over the last 50 years, Kenya has also experienced significant decline in the populations of other wildlife species such as wildebeest, gazelles, buffaloes, lions, leopards and cheetahs [6] [7].

The results of a recent aerial wildlife survey in the southern Kenya and Northern Tanzania region, stretching from the Amboseli-Chyulu-Kilimanjaro-Loliondo area to the Magadi-Natron region, indicated a dramatic decline in a number of large herbivore species between 2007 and 2010 [8]. In the Amboseli area for example, the wildebeest declined by about $83 \%$ from 18,538 to 3098 while zebra and buffalo declined by $71 \%$ and $61 \%$ from 15,328 to 4432 and 588 to 231 individuals, respectively [9]. The population decline was even higher for the wildebeest and Lesser Kudu. Similar wildlife change has been recorded in the Maasai Mara Ecosystem (MME) which is one of the key wildlife areas in Kenya supporting an exceptionally large and diverse population of wildlife [10]-[14]. In 2007, the area was declared the 8th wonder of the world especially due to the magical annual wildebeest migration. It is also in the UNESCO tentative list as a World Heritage Sites. Previous surveys in the area have indicated a 70\% decline in the resident wildlife within the last five decades [13]-[16].

Based on the above scenarios, it is an indisputable fact that Kenya's cherished wildlife heritage is becoming more and more endangered now than ever before. There is, therefore, a big challenge in ensuring that the current generations are able to transfer the wildlife heritage of their times to the generations of the future as envisaged in the national constitution [17]. This issue raises the need to establish whether societies in the country are noticing the on-going wildlife population changes in their local areas and the dilemma facing the valued heritage.

The Kenyan history has been associated with a close interaction between people and wildlife within which the challenge of human-wildlife conflict has continued to grow especially among farmers and pastoralists. During the pre-colonial times before 1885, wildlife heritage management in Kenya was predominantly a communal agenda, and the indigenous utilization of wildlife varied according to the needs and cultural practices of different ethnic groups. Records show that at this time, most of the country was characterized by lots of wildlife. According to [18] the Athi-Kapiti plains, probably in the vicinity of the proposed site for the Konza Techno City, for example, was at that time stocked with an amazing variety of wildlife, almost like an ocean of many different animals such as zebra, giraffe, impala, Thomson's gazelle, Grant's gazelle, hartebeest, wildebeest, and oryx in their hundreds upon endless hundreds as far as the eye could see. With the coming of the early explorers from Europe, the Middle East and other parts of the world, the previously unknown wildlife heritage in Africa was quickly revealed to the rest of the world and became a major attraction for sport hunting, ivory trade and tourism.

During his expedition as the first former USA president ever to visit Kenya in 1909, Theodore Roosevelt is said to have shot and killed not less than 296 animals including nine lions, eight elephants, thirteen rhinos (including nine white rhinos), six buffaloes and two bongo antelopes [18]. According to [19] the seventy-year colonial legacy in Kenya was marked by widespread alienation of people from the wildlife heritage which they previously closely associated with and relied on in their own different ways. The tough legislation in favour of the protectionist or fortress wildlife conservation approach created conflicts that persist until now [19]. Since independence in 1963, the various governments of the day in Kenya have continued to stress the need for people to live in harmony with the wildlife heritage. However, the increasing demands associated with the daily needs of the people such as food, water, shelter, pasture and energy among others has heightened the competition for resources between people and wildlife. The main loser in this competition has mainly been the wildlife whose populations have continued to decline.

According to [20], wildlife managers in Africa increasingly recognize that the survival of the remaining wildlife populations in the continent depends upon the willingness and ability of the people living in wildlife rich areas especially those adjacent to national parks and nature reserves to co-exist with wildlife. Consequently, the 
assessment of public attitudes and perceptions towards conservation has recently become important themes in some wildlife conservation studies [21]-[23]. Assessment of wildlife population trends using public knowledge have been used by a number of studies in Africa such as [24] [25] in which a strong correlation between public perception and actual scientific counts were noted. Understanding the factors influencing society attitudes is important in enabling wildlife managers to implement approaches that attract and win stakeholder support including the public.

One of the big questions in Africa is whether the local people, especially those living in wildlife rich areas, many of whom have inadequate formal education can appreciate and comprehend the on-going trend in wildlife population change in their local areas or not. One key assumption is that public reaction or inaction to the widespread challenge of wildlife decline should start with a personal appreciation of the problem. But very few studies have attempted to compare the degree of accuracy in public perceptions on wildlife population change against the real situation on the ground based on scientific wildlife population monitoring. This is important to know because the day-to-day contemporary wildlife conservation efforts by governments in collaboration with local and international conservation agencies will seriously be compromised if the general public do not comprehend and appreciate the fact that their wildlife heritage is degrading. The aims of the study were therefore to: 1) determine the wildlife population trends in the in the Mara Enoonkishu conservancy from the eyes and minds of the public through public consultations, 2) assess the recent trends in wildlife populations within the area based on actual scientific counts by the various wildlife management agencies on the ground, and 3) compare the two patterns and establish whether they are similar or not.

\section{Materials and Methods}

Enoonkishu Conservancy $\left(1^{\circ} 01^{\prime} 1^{\circ} 06^{\prime} \mathrm{S}\right.$; $\left.35^{\circ} 12^{\prime} 35^{\circ} 19^{\prime} \mathrm{E}\right)$ is located on the northern edge of the Maasai Mara Ecosystem (MME) within Narok County (Figure 1). It forms part of the greater Mara ecosystem which covers about $6000 \mathrm{~km}^{2}$ [26]. The study area is bordered to the south by the former Koiyaki Group Ranch where the Mara Naboisho community conservancy has also been established. It is bordered by the Mara River to the west which is a lifeline for the world famous Masai Mara National Reserve (Figure 1). The Enoonkishu Conservancy comprises of landscapes which area dominated by acacia thicket, grassland and forest. The mixed vegetation makes the area suitable to a wide range of wildlife species including herbivores (elephants, hippos, elands, giraffes, Thomson's gazelles, Grant's gazelles, wildebeests, common zebras, black and white Colobus monkeys and klispringers among others), carnivores (lions, leopards, spotted hyenas, black backed jackals and wild dogs among others), and birdlife (Maasai ostriches, kori bastards, weaver birds, starlings, vultures, and eagles).

The community conservancy with an area of 10,000 ha or 25,000 acres was established in 2008 by 1200 community members of the former Lemek Group Ranch which was sub-divided in 1999 and the members issued with their individual land title-deeds. The conservancy was established after 1200 land owners voluntarily agreed to contribute part of their private land towards wildlife conservation and tourism. The other members of the conservancy consist of the external investors who approached the conservancy members and leased land to establish private tourism business facilities within the conservancy mainly in the form of tented camps and camp sites.

The Enoonkishu Conservancy, like many others in the country, was established as a community response to the emerging challenges associated with the privatization of the former communal group ranches. The privatization opened doors for experiments on a wide range of alternative land uses including agriculture and the selling of land for quick and short term economic gain. The two alternatives did not seem to meet the traditional and long-term goal of ensuring direct economic gains from wildlife heritage in addition to livestock husbandry. The latter was significantly affected by the group ranch privatization and sub-division of land into small parcels. The livestock carrying capacity was significantly reduced and restricted to the owners' land parcel (60 - 150 acres) which was inadequate for the traditional roaming of livestock in search of pasture particularly during the dry season. Unlike the livestock, wildlife which is considered as state property in Kenya is able to roam freely unless obstructed by widespread property fencing.

After weighting the implications of land sub-division, the local people opted for wildlife conservation and tourism through the consolidation of private land, hence the idea of a community conservancy. The conservancy model provides an integrated framework which enables the local people to benefit from controlled livestock keeping and the additional income from the monthly or annual lease fees paid by external wildlife tourism 


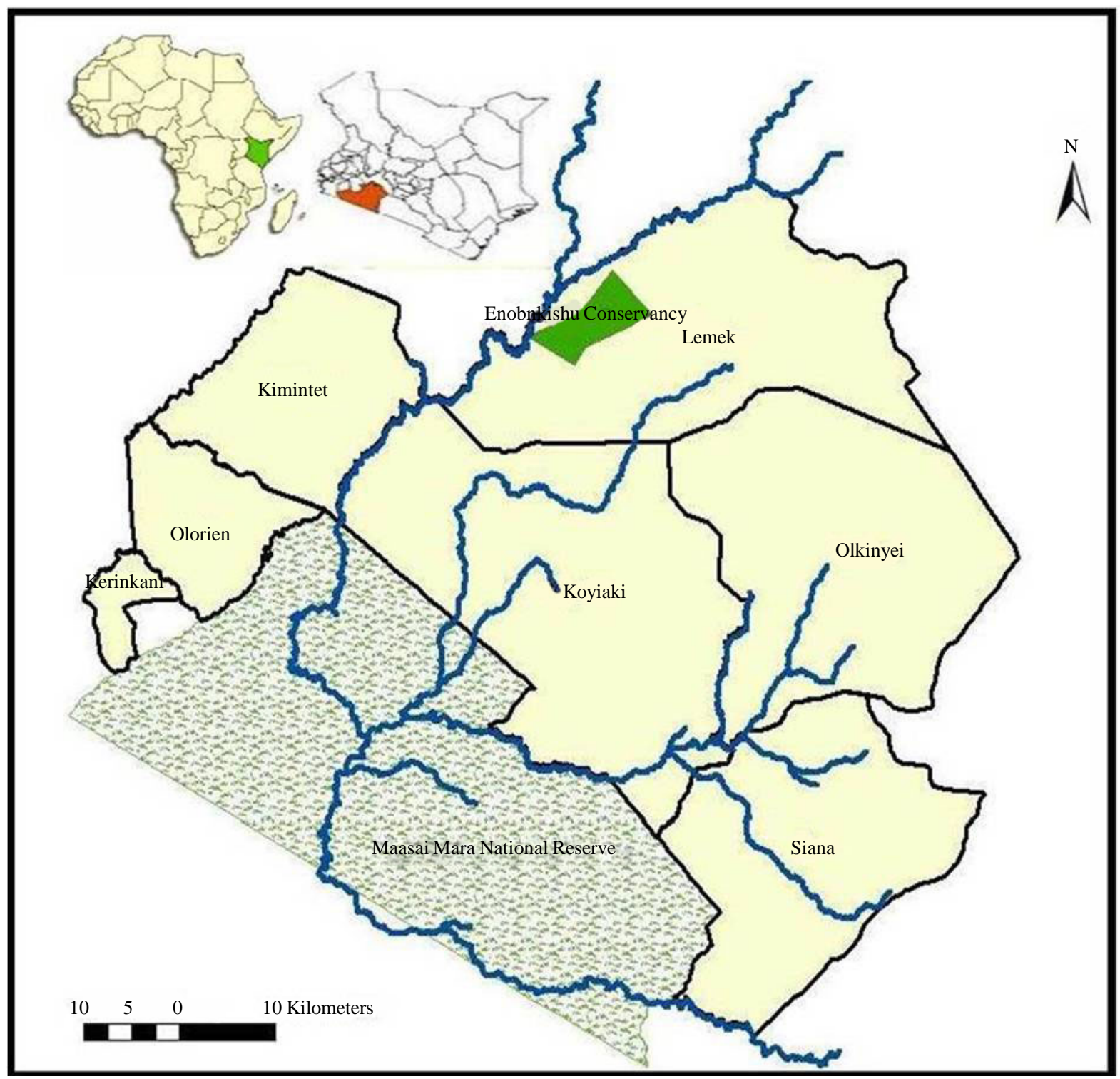

Figure 1. Location of Enoonkishu conservancy in the Mara Region.

investors. The latter usually enter into agreements with the local community which allow them to establish exclusive high-end tourism facilities within the conservancy to exploit the numerous wildlife attractions outside the national parks. The success of the community conservancy model however requires a harmonious co-existence by people, their livestock and the wildlife in the area.

The solicitation of public views on wildlife population trends was based on household surveys undertaken in 2012 using a standard questionnaire which was administered to 115 randomly selected households out of a total of the 1200 households belonging to conservancy members. Each household was allocated one respondent who had to be above 18 years with preference given to the oldest household member who had a clear history of the wildlife trends in the area. The 10\% sample households were selected by assigning all the 1200 households a numerical number and then selecting the 115 randomly from the pool using the hat method. The household numbering was based on the system used during the 2009 national population census. The actual interviews were preceded by a pilot survey using a sample of 15 respondents to gauge their comprehension of the study questionnaire after which some questions were adjusted before final administration in accordance with [27].

The interview schedule for the household survey included questions on; 1) the wildlife species which according to household respondent were dominant in the conservancy and were encountered almost every other week, 
2) the wildlife species which according to the respondent were considered rare in the conservancy and only encountered once a month, 3) the wildlife species whose number was increasing according to respondent, 4) the wildlife species whose number was decreasing according to the respondent, and 5) the wildlife species which according to respondent had totally disappeared from the conservancy and were not sighted in the last 10 years. The public perception timeframe was estimated at 50 years (1962-2012) based on the age distribution of the respondents as an indication of their interaction duration with the study area. The public views on wildlife species in the area were later compared with actual wildlife counts for the 1993-2003 period as determined through direct animal counts by the Kenya Wildlife Service (KWS) and the International Livestock Research Institute (ILRI) which was within the (1962-2012) public perception timeframe.

The actual wildlife population numbers were determined from existing secondary data provided by KWS and LRI for the 5 year period in 1998-2003 which was approximately a decade before the 2012 household survey. The KWS database was based on four wildlife species namely: elephant, buffalo, giraffe and eland as estimated through aerial survey in the greater Mara region. The ILRI records were based on ground surveys undertaken in the greater Mara region in 1999, 2002 and 2010 for a total of 34 species including the ones in the KWS survey records. In the cases where the same species was appearing in the two databases with different counts, an average of the two records was calculated and used in the trend analysis. The primary data was then coded and integrated into a common MS-Excel spreadsheet platform. Simple linear correlation analysis was undertaken to assess the variability of wildlife populations against time in years. The coefficient of determination $\left(\mathrm{r}^{2}\right)$ was used to indicate the proportion of the variance in the dependent variable that was predictable from the independent variable. All analyses were carried out in SPSS Version 20.

\section{Results and Discussion}

The majority of the respondents (49\%) were aged 29 - 39 years with only 6\% above 51 years. Based on the adulthood benchmark age of 18 years, the 29 - 39 age bracket had a minimum exposure of 11 years (2001-2012) and a maximum exposure of 21 years (1991-2012) to the wildlife population change in the area. This was considered as a suitable range for comparative analysis with the actual wildlife counts for the 1998-2003 period based on the KWS and ILRI records. 32\% of the respondents had no formal education while the rest were educated with $25 \%, 28 \%$ and $15 \%$, respectively, having primary, secondary and tertiary education (college and university). A vast majority of the respondents (89\%) were residents in the conservancy by birth with only $41 \%$ having formal employment and 30\% and 29\%, respectively, being unemployed and self-employed. That means that almost $60 \%$ were based in the conservancy most of the time and would be able to comprehend the on-going changes in wildlife population. Further, most of them had a mean residence duration of 23 years in the conservancy which meant that they had lived there since 1989 while the majority (95\%) had lived there for a period of 21 - 25 years. This was all within the actual wildlife counts for the 1998-2003 period based on the KWS and ILRI records.

The dominant wildlife species in the area according to $39 \%$ of the respondents was the elephant followed by the by the zebra with $35 \%$ of the responses (Table 1). The elephant was also ranked by $40 \%$ of respondents as the most problematic species in terms of human-wildlife conflict. The other species which were considered dominant by the public included the buffalo and giraffe. From this it appeared the dominant wildlife species in the eyes and minds of the public were those which were very common either in terms of their large numbers, conspicuous stature (e.g. giraffe and buffalo), or as the most destructive in the livelihoods of the people. $4 \%$ of the respondents viewed the lion and Grant's gazelle as dominant species while less than $4 \%$ indicated the buffalo, giraffe, monkey, hare, and warthog as the dominant species. $40 \%$ of the respondents in the Mara Enoonkishu Conservancy perceived the rhino as the rarest wildlife species in the area followed by wild dogs (23\%) and cheetah (10\%). $45 \%$ of the respondents attributed the declining numbers of the rhino from the area to increased poaching (Table 1). 20\% of the respondents considered the wild dog as the rarest predator species in the area followed by the cheetah (10\%) as shown in Table 1 . The different perceptions could be attributed to the influence on wildlife distribution by finer ecological differences in different parts of the conservancy where individual respondents were located. These environmental differences were not considered in the study.

Regarding the question of whether any wildlife species had almost completely disappeared from the area as an indicator of severe population decline, $23 \%$ of the respondents thought that no wildlife species had disappeared from the area. However, $40 \%$ of the respondents indicated that the rhino had almost disappeared from the 
Table 1. Perception of wildlife population and characteristics.

\begin{tabular}{|c|c|c|c|c|c|}
\hline $\begin{array}{l}\text { Animal } \\
\text { species }\end{array}$ & Dominant species (\%) & Rare species (\%) & Problematic species (\%) & Most valued species (\%) & Disappearing species (\%) \\
\hline Elephant & 39 & 4 & 40 & 29 & 3 \\
\hline Rhino & 0 & 25 & 0 & 12 & 40 \\
\hline Zebra & 35 & 3 & 2 & 3 & 4 \\
\hline Buffalo & 4 & 4 & 7 & 5 & 4 \\
\hline Lion & 4 & 3 & 18 & 18 & 3 \\
\hline Cheetah & 0 & 10 & 3 & 4 & 6 \\
\hline Wild dog & 0 & 20 & 0 & 7 & 7 \\
\hline
\end{tabular}

area, followed distantly by wild dogs (7\%) and cheetah (6\%). The perception of upto85\% of the respondents indicated that there was an overall increase in wildlife population in the area. This finding was similar to the one by [28] who found out that wildlife species such as rhino, cheetah, wild dogs and leopard which are generally rare and endangered can be perceived by local community as having decreased drastically or even disappeared altogether contrary to their actual status.

Figure 2 shows the 1998-2003 trends in the wildlife species whose populations were on the increase based on the KWS and ILRI counts. The herbivore species with increasing populations included the rhino $\left(\mathrm{r}^{2}=0.9992\right)$, impala $\left(r^{2}=0.9824\right)$, Grant's gazelle $\left(r^{2}=0.7052\right)$, Thomson's gazelle $\left(r^{2}=0.6965\right)$, elephant $\left(r^{2}=0.5798\right)$, and topi $\left(r^{2}=0.4426\right)$ (Figure 2). According to this, the variance in the populations of the rhino, impala and Grant's gazelle was higher during that period than those of the elephant and topi. The coefficient of determination indicated that over $98 \%$ of the variance in the population of the rhino was predictable from the passage of time in terms of years compared to $58 \%$ in the case of the elephant (Figure 2). The predator species whose numbers were on the increase included the lion $\left(r^{2}=1.000\right)$, cheetah $\left(r^{2}=0.9093\right)$ and hyena $\left(r^{2}=0.8462\right)$ as shown in Figure 3 . The coefficient of determination indicated that over $90 \%$ of the variance in the populations of the lion and cheetah was predictable from the passage of time in terms of years compared to $84 \%$ in the case of the hyena (Figure 3). The species on the decline according to the actual counts included the crocodile $\left(r^{2}=0.9826\right)$, eland, $\left(r^{2}=0.7208\right)$, buffalo $\left(r^{2}=0.6952\right)$ and leopard $\left(r^{2}=0.2266\right)$ as shown in Figure 4 .

The findings on the elephant population change from the public perception survey as well as the actual wildlife counts based on the KWS and ILRI counts for the 1998-2003 period appeared to indicate that the establishment of conservancies around the Maasai Mara National Reserve (MMNR) might have encouraged the movement of more elephants into the conservancy from the MMNR. However, this finding contradicted the findings in the study by [29] who established that there were six to seven-fold more elephants in the MMNR than the number in the surrounding group ranches. The study by [29] established that most of the elephants in the MMNR were concentrated in the southern zone, away from the areas where intensive cattle grazing was practiced especially in the northern border of the reserve where the Mara Enoonkishu Conservancy is located.

The increase in key predator species such as the lion, cheetah and hyena within the Masai Mara area as established in the actual KWS and ILRI counts could explain the public perception on human-wildlife conflicts in Enoonkishu Conservancy where the lion was considered as a major problem (Table 2). Both the lion and hyena have been perceived as the most disturbing in terms of livestock predation in other areas such as the Nguruman Hills [30] and also in the Amboseli ecosystem [31]. The public view that the rhino was the rarest wildlife species in the Mara Enoonkishu Conservancy was in agreement with the study by [29] where only 11 rhinos were recorded in the MMNR during a count in 2002 where none was recorded in the adjacent community areas. However, the public perception on the rhino decline was contrary to the actual status based on the KWS and ILRI records for the 1998-2003 period which indicated an increase in the number of rhinos although the increase was probably in the MMNR (Table 2). The declining perception for the wild dog and cheetah could explain why the public did not consider the two as among the problematic predators in the area.

The overall public perception that wildlife population in the study area was increasing was contrary to the findings from actual wildlife counts in other studies in the Mara region which indicated a decline [10]-[16] [28] [32]. However, the focus for these studies was not on the Mara Enoonkishu Conservancy. The public view on the matter in the Mara Enoonkishu Conservancy if accurate could confirm the realization of the expectation in Kenya that community and private conservancies could be the only hope for securing wildlife outside the 


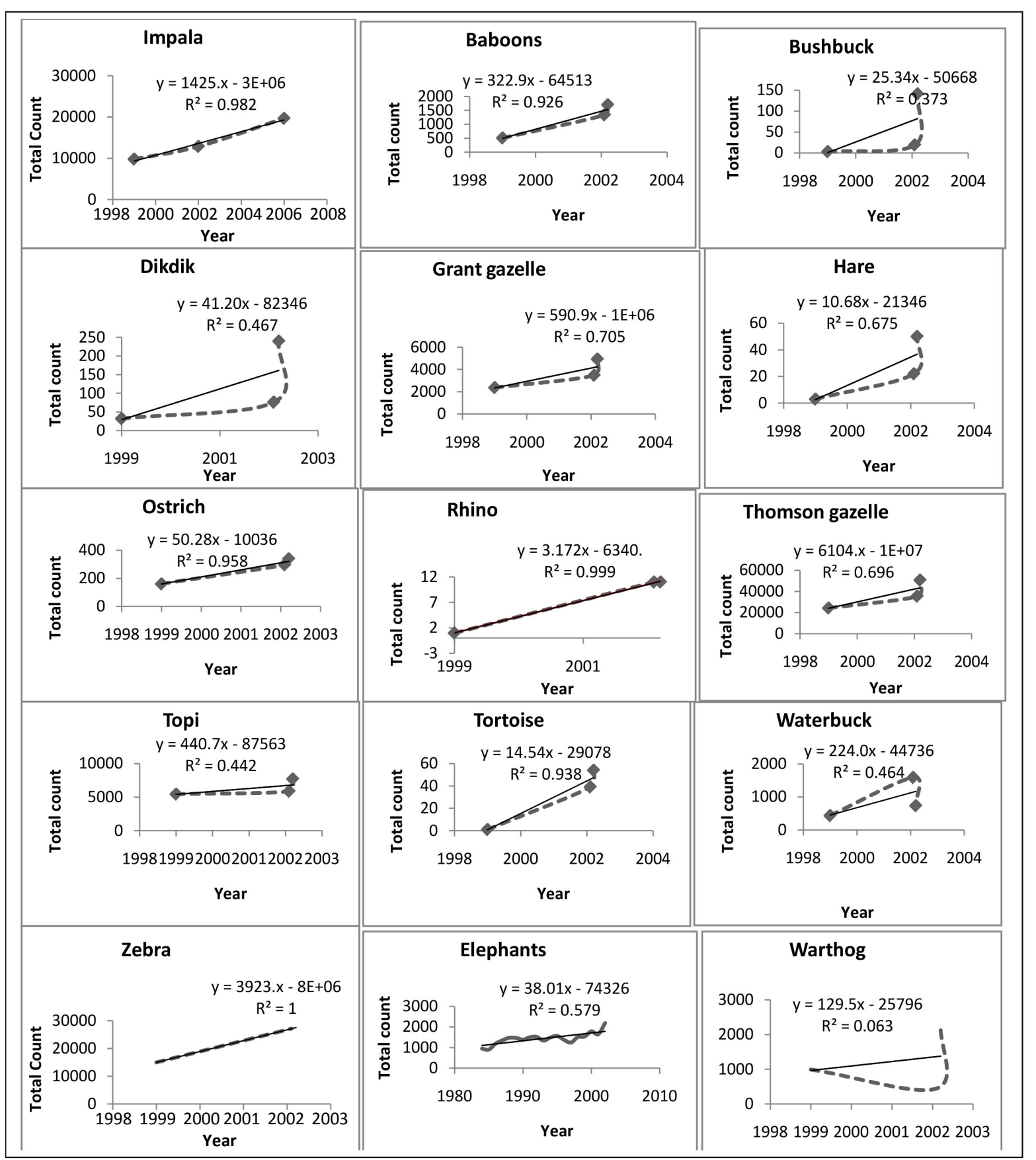

Figure 2. Herbivore species on the increase.

protected areas by partnering with local community and other landowners in wildlife rich areas around the country. The success of the conservancy model, however, requires good incentives to community and private entities such as suitable compensation mechanisms, conducive property rights, attractive tourism investor contracts with investors in order to induce conservation.

\section{Conclusion}

The findings showed that only 30\% - 40\% of the perceived dominant wildlife species in Mara Enoonkishu Conservancy was consistent with the actual status on the ground. Similarly, $50 \%$ of the perceived wildlife species 


\section{Lion}

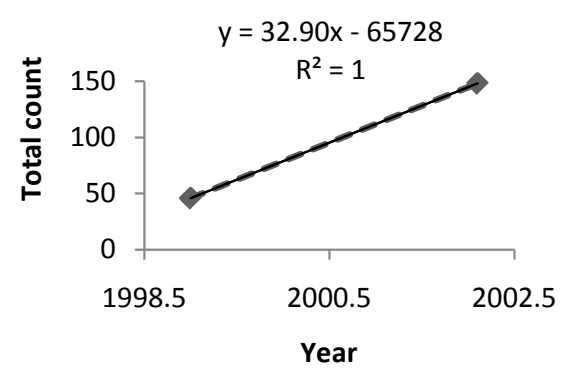

\section{Hyena}

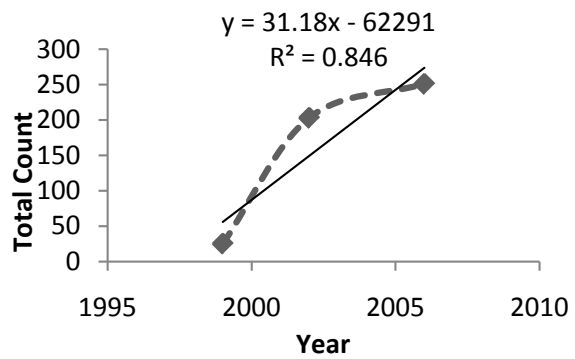

Cheetah

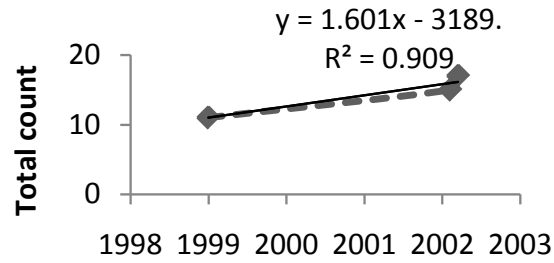

Year

Figure 3. Carnivore species on the increase.

\section{Buffalo}

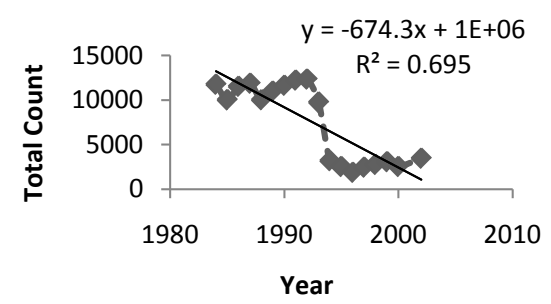

Eland

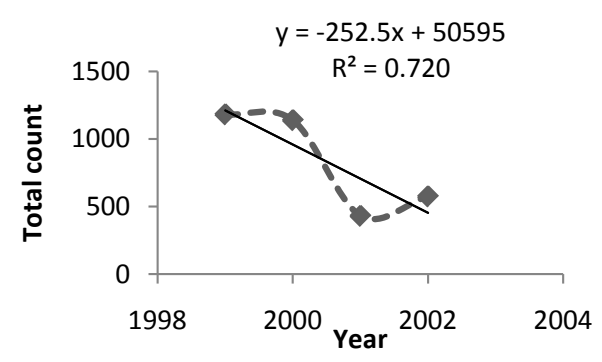

Giraffe

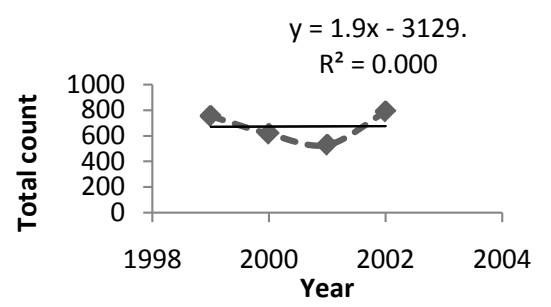

Hippos

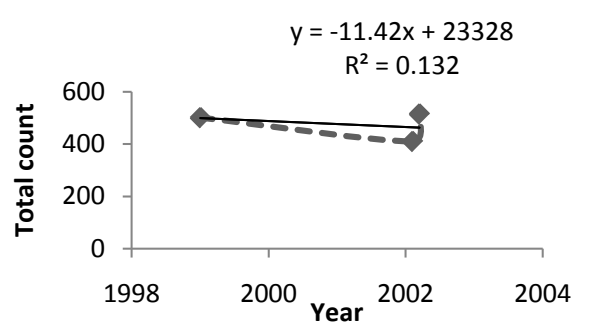

(a)

\section{Leopard}

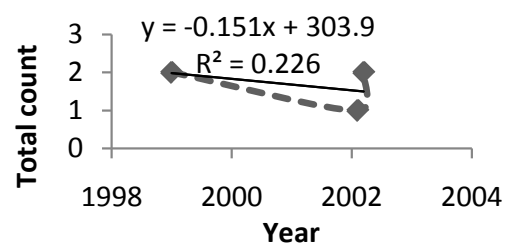

\section{Crocodile}

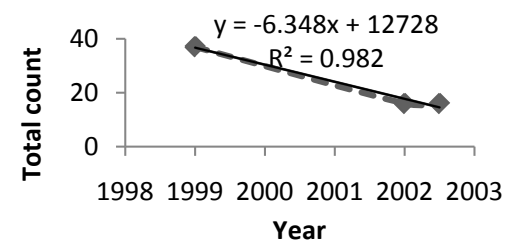

(b)

Figure 4. Wildlife species on the decline. (a) Herbivores; (b) Predators. 
Table 2. Summary of findings.

\begin{tabular}{|c|c|c|}
\hline & Herbivores & Predators \\
\hline Dominant species in the eyes of the public & $\begin{array}{l}\text { Buffalo } \\
\text { Elephant } \\
\text { Gazelle } \\
\text { Giraffe } \\
\text { Warthogs } \\
\text { Zebra }\end{array}$ & Lion \\
\hline Increasing species according to actual field count & $\begin{array}{l}\text { Elephant } \\
\text { Grant's gazelle } \\
\text { Impala, } \\
\text { Rhino } \\
\text { Thomson's gazelle } \\
\text { Topi } \\
\text { Zebra }\end{array}$ & $\begin{array}{l}\text { Cheetah } \\
\text { Hyena } \\
\text { Lion, }\end{array}$ \\
\hline Rare species in the eyes of the public & $\begin{array}{l}\text { Buffalo } \\
\text { Eland } \\
\text { Gazelles } \\
\text { Impala } \\
\text { Rhino } \\
\text { Topi } \\
\text { Tortoises } \\
\text { Warthog } \\
\text { Waterbuck }\end{array}$ & $\begin{array}{l}\text { Cheetah } \\
\text { Hyena } \\
\text { Leopard } \\
\text { Wild dogs }\end{array}$ \\
\hline Decreasing species according to actual field count & $\begin{array}{l}\text { Buffalo } \\
\text { Eland } \\
\text { Giraffe } \\
\text { Hippo }\end{array}$ & Leopard Crocodile \\
\hline
\end{tabular}

whose population was on the decline according to the public view was consistent with the actual situation on the ground. It appeared that public perception on the dominant species was influenced by keystone, charismatic or umbrella species in the area. The perception was also influenced by the risky and dangerous species such as the elephant, lion, leopard, cheetah and hyena which were traditionally associated with human and livestock injuries and death. It was also influenced by competition for scarce resources as in the case of the zebra which usually competes unaggressively with livestock for pasture. The study established mixed or confused public perceptions and views on the buffalo and gazelles which were considered dominant by certain people and rare by others. Based on these observations, it was concluded that the public view on the wildlife population trend was not similar to the actual wildlife population status on the ground based on scientific monitoring.

The overall conclusion here indicates that public perception might not be realiable in determining the actual trend in wildlife population in rich wildlife heritage areas. However, the findings from the Mara Enoonkishu Conservancy showed that public perception on wildlife population trends was probably influenced more local factors such as landform and vegetation characteristics which have a strong impact on wildlife distribution. These factors were not considered in the study thereby reducing the capacity for a clear explanation of the public views and perceptions. The scope of this study did not include factors such as household location, physiography, vegetation cover, seasonal factors, wildlife migration, and human-wildlife conflict. This might be interesting to consider in other public wildlife perception studies.

The indication that the establishment of community conservancy was attracting elephants from the protected area due to improved public-wildlife relations needs to be confirmed in an empirical study based on actual wildlife counts. Such a study could also determine whether the increased number of tourists and tourism infrastructure in protected areas such as the Masai Mara National Reserve might be responsible for such movements as widely speculated. If this is confirmed, it could scientifically confirm the public view in this study which identified the elephant as a key human-wildlife species. If this is the case, then a sustainable solution for this problem is required within community conservancies in the Mara region and other areas such as Amboseli, Laikipia and Samburu in-order for the people in such areas to continue entertaining and co-existing with such species.

\section{References}

[1] Western, D., Russell, S. and Cuthill, I. (2009) The Status of Wildlife in Protected Areas Compared to Non-Protected 
Areas of Kenya. PLoS ONE, 4, e6140.

[2] Ogutu, J.O., Owen-Smith, N., Piepho, H.-P. and Said, M.Y. (2011) Continuing Wildlife Population Declines and Range Contraction in the Mara Region of Kenya during 1977-2009. Journal of Zoology, 285, 99-109. http://dx.doi.org/10.1111/j.1469-7998.2011.00818.x

[3] KWS (2012) KWS Security Database Law Enforcement Statistics. Unpublished Data. KWS, Nairobi.

[4] Norton-Griffiths, N (2000) Wildlife Losses in Kenya: An Analysis of Conservation Policy. Natural Resource Modeling, 13, 13-34. http://dx.doi.org/10.1111/j.1939-7445.2000.tb00026.x

[5] Douglas-Hamilton, I., Douglas-Hamilton, Ö. and Jackman, B. (1992) Battle for the Elephants. Viking, London.

[6] Wanyonyi, E.W. (2012) Mobilizing Resources for Wildlife Conservation in Kenya beyond the 21st Century. The George Wright Forum, 29, 118-125.

[7] Lamprey, R.H. and Reid, R.S. (2004) Expansion of Human Settlement in Kenya's Maasai Mara: What Future for Pastoralism and Wildlife? Journal of Biogeography, 31, 997-1032. http://dx.doi.org/10.1111/j.1365-2699.2004.01062.x

[8] Kenya Wildlife Service \& Tanzania Wildlife Research Institute (2010) AERIAL total Count Amboseli-West Kilimanjaro Natron Cross Border Landscape Wet Season, March 2010.

[9] Ndambuki, S. and Kioko, J. (2009) Ground Total Game Count: Amboseli National Park and Kimana Wildlife Sanctuary. Unpublished KWS and ATE Report.

[10] Lamprey, R.H. (1984) Maasai Impact on Kenya Savannah Vegetation: A Remote Sensing Approach. Unpublished Ph.D. Thesis, University of Aston, Birmingham.

[11] Said, B.M. (1985) Population Trends of Ungulates in and around Kenya’s Maasai Mara Reserve; Serengeti II: Dynamics Management, and Conservation of an Ecosystem. University of Chicago Press, Chicago.

[12] Stelfox, J.G., Peden, D.G., Epp, H., Hudson, R.J., Mbugua, S.W. and Agatsiva, J.L. (1986) Herbivore Dynamics in Southern Narok, Kenya. Journal of Wildlife of Management, 50, 339-347. http://dx.doi.org/10.2307/3801925

[13] Ottichilo, K.W. (2000) Wildlife Dynamics: An Analysis of Change in the Masai Mara Ecosystem of Kenya. PhD Thesis, Wageningen University, Wageningen.

[14] Reto-o-Reto (2007) Losing Ground in the Mara, Fast But Not Inevitable. Policy Briefs No. 3.

[15] Homewood, K., Lambin, E.F. Coast, E., Kariuki, A., Kikula, I., Kivelia, J., Said, M., Serneels, S. and Thompson, M. (2001) From the Cover: Long-Term Changes in Serengeti-Mara Wildebeest and Land Cover: Pastoralism, Population, or Policies? Proceedings of the National Academy of Sciences of the United States, 98, 12544-12549. http://dx.doi.org/10.1073/pnas.221053998

[16] Wakhungu, J.W., Wairungu, L., Agwanda, B., Awori, P., Isiche, J., Itela, S. and Njumbi, S. (2010) Towards a National Biodiversity Conservation Framework. Proceedings of the International Conference on Biodiversity, Land-Use and Climate Change, Nairobi, 15-17 September 2010.

[17] Government of Kenya (2010) The Constitution of Kenya. Government Printer, Nairobi.

[18] Miller, C. (1971) The Lunatic Express. Penguin, London.

[19] Waithaka, J. (2012) Historical Factors that Shaped Wildlife Conservation in Kenya. The George Wright Forum, 29, 2129.

[20] David, J.C., Gichohi, H., Reid, R., Mwangi, A., Chege, L. and Sawin, T. (2003) Interactions between People and Wildlife in Southern Kajiado District, Kenya. LUCID Working Paper Series No. 18.

[21] Newmark, W.D., Manyanza, D.N. and Deo-Grati, M.G. (1984) The Conflict Wildlife and Local People Living Adjacent to Protected Areas in Tanzania: Uman Density as a Predictor. Conservation Biology, Cambridge University Press, Cambridge.

[22] Kasiki, S. (1996) Human-Elephant Conflicts in the Areas Adjacent to Tsavo National Park, Kenya. Progress Reports to Kenya Wildlife Service.

[23] Ashenafi, Z. (2001) Common Property Resource Management of an Afro-Alpine Habitat: Supporting a Population of the Critically Endangered Ethiopian Wolf (Canis simensis). PhD Thesis, University of Kent, Kent.

[24] Gandiwa, E. (2012) Local Knowledge and Perceptions of Animal Population Abundances by Communities Adjacent to the Northern Gonarezhou National Park, Zimbabwe. Tropical Conservation Science, 5, 255-269. www.tropicalconservationscience.org

[25] Danielsen, F., Jensen, P.M., Burgess, N.D., Coronado, I., Holt, S., Poulsen, M.K., Rueda, R.M., Skielboe, T., Enghoff, M., Hemmingsen, L.H., Sørensen, M. and Walzl, K.P. (2014) Testing Focus Groups as a Tool for Connecting Indigenous and Local Knowledge on Abundance of Natural Resources with Science-Based Land Management Systems. Skindergade, Copenhagen, Denmark.

[26] Sinclair, C.G. (1994) Wildlife Ecology and Manangement. Blackwell Publishers, Oxford. 
[27] De Vaus, D.A. (1996) Surveys in Social Research. 4th Edition, University College of London Press, London.

[28] Groom, R. and Brand, H. (2011) Carnivore Densities in Gonarezhou National Park. Unpublished Report, Zimbabwe Parks and Wildlife Management Authority, Harare.

[29] Reid, R.S., Rainy, M.E., Ogutu, J., Kruska, R.L., Kimani, K., Nyabenge, M., McCartney, M., Kshatriya, M., Worden, J.S., Ng'ang'a, L., Owuor, J., Kinoti, J., Njuguna, E., Wilson, C.J. and Lamprey, R.H. (2003) People, Wildlife and Livestock in the Mara Ecosystem: The Mara Count 2002. International Livestock Research Institute, Nairobi, Kenya.

[30] Mwathe, K. (2006) Human Wildlife Conflict in the Nguruman Area of South Rift. Unpublished Masters Project Report, University of Nairobi, Kenya.

[31] Manoa, D.O. and Mwaura, F. (2016) Predator-Proof Bomas as a Tool in Mitigating Human-Predator Conflict in Loitokitok Sub-County, Amboseli Region of Kenya. Natural Resources, 7, 28-39. http://dx.doi.org/10.4236/nr.2016.71003

[32] Serneels, S. and Lambin, E. (2001) Impact of Land-Use Changes on the Wildebeest Migration in the Northern Part of the Serengeti-Mara Ecosystem. Journal of Bigeography, 28, 391-408. http://dx.doi.org/10.1046/j.1365-2699.2001.00557.x

\section{Submit or recommend next manuscript to SCIRP and we will provide best service for you:}

Accepting pre-submission inquiries through Email, Facebook, LinkedIn, Twitter, etc. A wide selection of journals (inclusive of 9 subjects, more than 200 journals)

Providing 24-hour high-quality service

User-friendly online submission system

Fair and swift peer-review system

Efficient typesetting and proofreading procedure

Display of the result of downloads and visits, as well as the number of cited articles

Maximum dissemination of your research work

Submit your manuscript at: http://papersubmission.scirp.org/ 